\title{
TRADISI MASYARAKAT SEBAGAI KEKUATAN SINKRETISME DI TRUCUK, KLATEN
}

\author{
Oleh: \\ Sutiyono \\ Staf Pengajar FBS UNY
}

\begin{abstract}
This study aims to prove that the societal tradition in in Trucuk alive and growing dynamically, because of the strength of syncretism. This research was conducted in rural areas Trucuk District, Klaten, Central Java. The time to conduct field studies began in March to October 2006. As a research subject, namely: farmer, caretaker shrine, the pilgrims, paranormal, dalang, arts reog elders, chairman slawatan, modin, lurah, Muhammadiyah activists, political elites, religious teachers, kyai, mubaligh, congregational recitation, and the priest mosque. Methods of data collection is participant observer, depth interviews, and study of documentation. This study uses an ethnographic approach. The results showed that the societal tradition who are still be regularly performed of rural communities is slametan. Slametan an intangible form of social activism traditional ceremony which was attended by a group of people from different social groups to come together, accompanied by a serving dish and prayed the Islamic way. In gathering together, all of them understand each other and can understand each other. The discrepancies in all respects to be thin and fixed on the formation of community integration or syncretism. The strength of syncretism make the societal tradition in Trucuk alive and growing dynamically. So, the theory mentions that syncretism is the attempt to unify the different sects (Mulder, 1992) proved in this study.
\end{abstract}

Key words: societal tradition, slametan, syncretism..

\section{PENDAHULUAN}

Salah satu kehidupan tradisi masyarakat di Indonesia yang masih terlihat unik dan bersinar adalah tradisi masyarakat di Trucuk, Klaten, Jawa Tengah. Kenyataannya hingga sekarang masih terdapat kelompok-kelompok masyarakat yang menjalankan 
aktivitas tradisi berupa slametan atau ritual keselamatan di berbagai tempat. Aktivitas slametan yang sangat terkenal di kalangan masyarakat Jawa sering menjadi perdebatan, mengingat keberadaannya dianggap sebagai bentuk kepercayaan atau keagamaan masyarakat Jawa karena di dalam perwujudannya banyak mempergunakan doa-doa Islami.

Di sisi lain, aktivitas slametan dianggap sebagai bentuk tradisi masyarakat atau suatu kebudayaan masyarakat Jawa. Aktivitas slametan merupakan tindakan atau prilaku tradisi/budaya masyarakat Jawa. Koentjaraningrat (1980: 193) mengungkapkan bahwa kebudayaan dimaknai sebagai keseluruhan sistem gagasan, tindakan, dan hasil karya manusia dalam kehidupan masyarakat yang dijadikan milik diri manusia dengan cara belajar. Aktivitas slametan dalam pandangan Koentjaraningrat ini dapat dimaknai sebagai sistem tindakan dalam memelihara tradisi masyarakat.

Anggapan sebagai kepercayaan atau tradisi itu digambarkan oleh Geertz sebagai suatu kebudayaan yang kompleks. Ia menunjuk pada banyaknya variasi dalam upacara, pertentangan dalam kepercayaan, serta konflik-konflik nilai yang muncul sebagai akibat perbedaan golongan sosial atau menurutnya sebagai tipe kebudayaan: abangan, santri, priyayi (Geertz, 1989: 9). Namun demikian, perbedaan tipe kebudayaan yang mewujudkan kehidupan masyarakat plural, satu sama lain tetap berdasarkan pada wilayah geografi yang sama, yaitu di wilayah Jawa. Di dalam kelompok-kelompok masyarakat dengan tipe tradisi dan kebudayaan yang berbeda tercakup dalam struktur sosial yang sama, memegang banyak nilai yang sama, semuanya ini terdapat dalam aktivitas slametan. Oleh karena itu, aktivitas slametan sering dianggap sebagai perekat sosial atau integrasi masyarakat.

Namun demikian kehidupan tradisi masyarakat tersebut terganggu dengan masuknya arus budaya Islam murni. Dengan masuknya budaya Islam murni yang dibawa Muhammadiyah menekan tradisi masyarakat. Bentuk penekanannya adalah menganggap bahwa tradisi masyarakat bukanlah suatu cara dan 
peradaban yang Islami, tetapi cara-cara yang hanya akan menyuburkan $\mathrm{TBC}^{1}$. Hal tersebut disebabkan upacara slametan banyak menghadirkan sesaji dan kepercayaan akan hari-hari yang dikeramatkan. Itulah sebabnya sikap Muhammadiyah (Abdurrahman, 2003: 22) terhadap tradisi masyarakat itu tidak menunjukkan wajah yang bersahabat. Dapat dinyatakan bahwa hubungan Muhammadiyah dan tradisi masyarakat selama ini tampak kaku. Orang-orang Muhammadiyah enggan memasuki lingkaran tradisi masyarakat. Sebaliknya, para pelaku tradisi masyarakat juga enggan memasuki lingkaran Muhammadiyah yang dianggap menyeramkan itu.

Ketidaksenangan masyarakat Muhammadiyah terhadap tradisi selama ini memang dapat dibenarkan, mengingat sejak berdiri sampai tahun 80-an, organisasi Muhammadiyah dikendalikan oleh para ahli syariah yang tercermin dalam formalisasi syariah. Orang Islam yang melakukan peribadatan yang tidak sesuai syariah berarti masih dipengaruhi TBC. Oleh karena itu, pemberantasan tradisi masyarakat bermuatan TBC telah membentuk bangunan kesadaran (ideologi) orang Muhammadiyah. Oleh karena kuatnya ideologi tersebut, maka orang Muhammadiyah merasa kesulitan melepaskannya, bahkan ideologi pemberantasan TBC itu dipegang terus sampai sekarang. Orang-orang Muhammadiyah juga menganggap bahwa tradisi masyarakat itu baik yang mengandung TBC atau tidak, di dalamnya tidak terdapat manfaat yang diperoleh secara praktis. Warga Muhammadiyah beranggapan bahwa tradisi masyarakat itu justru bertentangan

1 TBC merupakan singkatan dari takhayul, bid'ah, dan churofat. Takhayul adalah kepercayaan terhadap sesuatu yang dianggap ada, padahal sebenarnya tidak ada. Bid'ah adalah perbuatan ibadah (ritual) yang dikerjakan tidak menurut contoh-contoh yang telah ditetapkan, termasuk menambah dan mengurangi ketetapan, tanpa berpedoman pada Al Qur'an dan Sunah Rasul. Churofat adalah ajaran yang tidak masuk akal. 
dengan ajaran Islam atau merupakan sesuatu yang mubazir (Berita Resmi Muhammadiyah No. 13, 2000: 37).

Meskipun ditekan oleh kebudayaan baru yang dibawa oleh kelompok sosial gerakan Islam murni, tradisi masyarakat di Trucuk tidak mengalami kegersangan, bahkan mengalami dinamika kebudayaan. Dinamika tradisi masyarakat itu berlangsung sejak jaman prasejarah, Hindu/Budha, Islam, kolonialisme hingga sekarang. Buktinya upacara slametan masih mengental di kalangan masyarakat Jawa di Trucuk. Dalam arti, meskipun tradisi slametan bercampur dengan kebudayaan ataupun kepercayaan lain (animisme, Hindu, Budha, Islam, dan sebagainya), tetapi roh tradisi masyarakat itu masih terlihat jelas. Bahkan, ketika ditekan budaya Islam murni, tradisi slametan tetap hidup subur. Seiring dengan masuknya arus budaya Islam murni besar-besaran sekarang ini, kenyataannya tradisi masyarakat di Trucuk masih hidup, dan banyak lokasi yang sekarang masih mengakar kehidupan tradisi masyarakat. Oleh karenanya, rumusan masalah yang dapat ditandaskan adalah kekuatan apa yang menjadikan tradisi masyarakat di Trucuk tetap hidup dan berkembang secara dinamis?

Berdasarkan rumusan masalah tersebut, dalam penelitian ini juga dirumuskan sebuah hipotesis yang menyebutkan bahwa kekuatan yang menjadikan tradisi masyarakat di Trucuk tetap hidup dan berkembang secara dinamis adalah kekuatan sinkretisme. Istilah sinkretisme berasal dari kata syin (dalam bahasa Arab) dan kretiozein, yang berarti mencampuradukkan unsur-unsur yang saling bertentangan. Demikian pula sinkretisme yang ditafsirkan berasal dari bahasa Inggris, yaitu syncretism yang diterjemahkan campuran, gabungan, paduan, dan kesatuan. Sinkretisme merupakan percampuran antara dua tradisi atau lebih, dan terjadi lantaran masyarakat mengadopsi suatu kepercayan baru dan berusaha untuk tidak terjadi benturan dengan gagasan dan praktek budaya lama. Terjadinya percampuran tersebut biasanya melibatkan sejumlah perubahan pada unsur-unsur budaya yang diikutsertakan. Dalam studi ini, sinkretisme dipahami sebagai percampuran antara unsur- 
unsur budaya yang menyatu yaitu animisme, Hindu, Budha, dan Islam.

Kebudayaan Jawa bercorak sinkretis, dalam arti terdapat perpaduan di antara dua atau lebih unsur budaya, misalnya budaya animisme, Hindu, Budha, dan Islam. Hal tersebut seperti dinyatakan Geertz sebagai agama Jawa. Agama Jawa ini tampak dari luar adalah Islam, tetapi setelah dilihat secara mendalam kenyataannya adalah agama sinkretis. Sepertinya tidak terjadi apa-apa bahwa sinkretisme itu menciptakan persatuan sebagai tujuan utama, akibatnya dogma-dogma dan ajaran-ajaran harus dikurbankan secara lahiriyah, tetapi di dalamnya dogma-dogma dan ajaranajaran masih dipergunakan. Dalam sinkretisme terlihat, bahwa namanya upacara Islami tetapi di dalamnya terkandung ajaran Hindu, Budha, dan animisme. Mulder (1992) meminjam Concise Oxford Dictionary untuk mendifinisikan sinkretisme, yakni usaha untuk menghilangkan perbedaan-perbedaan dan menciptakan persatuan antara sekte-sekte. Kekuatan sikretisme inilah yang menjadikan tradisi masyarakat atau kebudayaan Jawa tetap hidup dan berkembang secara dinamis.

\section{Cara Penelitian}

Dalam studi ini dilakukan di daerah Kecamatan Trucuk, Klaten, Jawa Tengah. Area wilayah Kecamatan Trucuk sebagian besar adalah tanah pertanian, menunjukkan bahwa Trucuk merupakan wilayah pedesaan yang sangat kental dihuni oleh masyarakat petani Jawa yang mendukung tradisi masyarakat berupa upacara slametan. Di samping subur kehidupan tradisi masyarakat, Trucuk juga merupakan suatu wilayah yang subur gerakan pemurnian Islam yang dibawa oleh kelompok sosial Muhammadiyah.

Subjek penelitian ini antara lain melibatkan para petani, juru kunci tempat keramat, para peziarah, paranormal, dalang wayang kulit, dalang wayang sadat, pemain dan sesepuh kesenian reog, ketua slawatan, modin/kaum/rois, lurah, kepala dukuh, sesepuh desa, elite dan aktivis Muhammadiyah, elite parpol, guru 
agama, kyai, santri, aktivis Nahdatul Ulama, mubaligh, jamaah pengajian, dan imam masjid. Dengan demikian subjek penelitian ini berasal dari kelompok sosial pendukung tradisi masyarakat dan pelaku gerakan pemurnian Islam.

Untuk memperoleh penjelasan secara komprehensip mengenai peristiwa sosial-budaya yang terjadi dalam masyarakat pedesaan Trucuk, yaitu mengenai sistem budaya yang dimiliki oleh kelompok tradisi masyarakat, dalam penelitian ini digunakan pendekatan etnografi. Melalui pendekatan etnografi (Spradley, 1997: 12), peneliti mempelajari peristiwa kebudayaan dengan mempresentasikan pandangan hidup subjek penelitian. Oleh karena itu, untuk mendapatkan data penelitian dipergunakan cara observasi, observasi partisipan, dan wawancara mendalam.

\section{PEMBAHASAN}

\section{Slametan dan Mitos Kepercayaan}

Salah satu tradisi masyarakat Jawa yang masih sering dilaksanakan masyarakat pedesaan adalah slametan. Slametan merupakan bentuk aktivitas sosial berwujud upacara yang dilakukan secara tradisional. Di Klaten masih banyak orang Jawa melakukan upacara slametan, karena mempunyai hajatan keluarga. Upacara slametan masih dianggap sebagai aktivitas penting untuk mencari keselamatan, ketenangan, dan terjadinya keseimbangan kosmos. Keseimbangan kosmos adalah terjaganya hubungan yang harmonis antara mikrokosmos (manusia) dan makrokosmos (tuhan atau dunia gaib). Jika terjadi disharmonisasi, maka akan terjadi malapetaka menimpa dunia bawah. Seperti dideskripsikan Geertz, slametan itu mengharmoniskan hubungan antara orang Jawa dengan danyang yang menguasai desanya (Geertz, 1989).

Tradisi slametan masyarakat di Trucuk dapat dibedakan dalam tiga macam. Pertama, slametan siklus hidup manusia yaitu slametan dalam rangka memuliakan peristiwa penting kehidupan orang Jawa, mulai dari peristiwa kelahiran, supitan, tetesan, 
pernikahan, sampai kematian. Slametan untuk peristiwa kelahiran antara lain: (1) brokohan, dan (2) bubaran. Slametan untuk peristiwa supitan/tetesan antara lain: (1) supitan/tetesan dan (2) selapanan. Slametan untuk peristiwa perkawinan antara lain: (1) midodareni (2) sepasaran, (3) tingkeban. Slametan untuk peristiwa kematian antara lain: (1) surtanah (2) hari ke3, ke-7, ke-40, ke-100, setahun, dua tahun, dan hari ke-1000. Kedua, slametan ziarah merupakan tradisi slametan yang dilakukan dengan melakukan suatu ritual yang diikuti oleh orang banyak (secara kolektif) dan sendiri (individu) ke tempat-tempat keramat, seperti makam, pohon, dan sendang. Secara kolektif dilakukan pada waktu-waktu yang telah ditentukan. Secara individual dilakukan dengan waktu bebas. Ketiga, slametan alam yaitu bentuk ritual yang dilakukan masyarakat agraris, guna melestarikan kehidupan tanaman padi, antara lain tedun, metik, dan Mboyong Mbok Sri.

Walaupun telah mengalami pergeseran, upacara slametan masih diselenggarakan oleh masyarakat Trucuk. Mereka memiliki mitos kepercayaan, bahwa roh-roh orang yang telah meninggal dunia dapat diajak berkomunikasi. Sewaktu orang Jawa sedang menyelenggarakan upacara slametan, mengundang para tetangga, saudara, dan handai taulan. Di samping itu yang lebih penting juga mengundang roh-roh para leluhur. Sebagai wujud rasa komunikasi dengan roh-roh leluhur, menu hidangan yang disajikan selain makanan (nasi) juga berupa sesaji. Bentuk sesaji bermacam-macam dan tujuannya dipersembahkan kepada roh-roh leluhur dan jagad gedhe. Dengan demikian upacara slametan itu tidak hanya ditujukan kepada sesama manusia, akan tetapi juga untuk makhluk kasat mata (tidak kelihatan). Namun, sekarang ini menu hidangan dan sesaji dalam bentuk apapun dan makhluk kasat mata sering tidak dipahami oleh orang Jawa. Sebagai gantinya menu hidangan dirubah menjadi makanan dalam bentuk mentahan, dan makhluk kasat mata dirubah menjadi Allah Tuhan Yang Maha Kuasa. Demikian pula sosok slametan yang dulunya merupakan bentuk persembahan, sekarang dirubah menjadi sedekah sebagai bentuk 
rasa syukur orang Jawa. Pergeseran ini tidak berlaku secara menyeluruh, karena masyarakat Jawa masih banyak yang menyelenggarakan upacara slametan dengan versi lama.

Aspek terpenting dalam upacara slametan adalah mitos kepercayaan. Tanpa hadirnya mitos kepercayaan, tentu upacara ini tidak memiliki roh, yang berarti akan mudah ditinggalkan oleh masyarakat pendukungnya. Sebagaimana Geertz (1989) menyebutkan, makna slametan adalah orang tidak akan merasa dibedakan dengan yang lain dalam satu komunitas wilayah. Kenyataanya orang yang tidak melakukan slametan dianggap ora umume wong atau dianggap bukan manusia, yang artinya dianggap tidak umum dalam kelompok sosialnya. Oleh karena itu, upacara slametan dianggap sebagai salah satu elemen tradisi masyarakat yang paling sulit untuk berubah dibanding dengan elemen kebudayaan Jawa yang lain.

Pada awalnya slametan merupakan bentuk upacara masyarakat Jawa penganut animisme. Ketika agama Islam masuk ke Jawa, para wali mengadakan pendekatan. Oleh para wali, unsurunsur dalam upacara tidak dihapuskan seluruhnya, tetapi beberapa doa diganti dan disesuaikan dengan doa Islami. Sebagaimana orang Jawa meninggal dunia dikirim doa melalu upacara slametan. Modin dalam memimpin upacara slametan dengan pengantar bahasa Jawa, dilanjutkan memimpin doa dengan berbahasa Arab. Dalam doa ini terdengar kata ngalaikum, bismillah, Mukammad, alkamdulilah, ngalamin, dan amien. Doa-doa berbahasa Arab sering dibaca dengan lidah Jawa, dan jika dijustifikasi dengan teori ilmu membaca Al-Qur'an tentu tidak benar, tetapi masyarakat memakluminya. Hal ini disebabkan, dalam slametan yang penting bukan terletak pada pesoalan benar-salah, tetapi lebih diutamakan pada persoalan harmonsasi warga masyarakat untuk berkumpul bersama, atau dalam pandangan Mulder (1992) menyebutkan bahwa mereka berkumpul bersama untuk menghilangkan perbedaan-perbedaan. 


\section{Slametan sebagai Bentuk Kekuatan Sinkretisme}

Persyaratan slametan memiliki jenis yang berbeda antara ritual yang satu dengan yang lainnya. Misalnya untuk slametan dalam rangka upacara perkawinan, kelahiran, kematian, dan yang lain berbeda, seperti dibicarakan di depan. Tetapi karena mengalami transformasi atau dinamika budaya, maka ritual apa saja yang diselenggarakan oleh suatu keluarga, bentuk ubarampe dalam suatu ritual slametan dianggap sama, yaitu selalu ada nasi dan lauk yang ditaruh dalam besek atau kerdus, meskipun kadang-kadang ditambah dengan jajan pasar. Cara ini ditempuh orang Jawa sekarang yang menghendaki aktivitas tradisi slametan lebih sederhana. Orang Jawa sendiri tidak mau repot-repot memasak untuk $u b a-$ rampe.

Bahkan kadang-kadang karena tidak mau repot, orang Jawa pesan pada pihak catering yang biasa melayani hidangan untuk slametan. Selain itu sering ubarampe tidak diwujudkan dalam bentuk makanan matang, tetapi berujud sembako atau bahan makanan (mentahan), misalnya beras, gula, teh, telur mentah, mie instant, dan roti.

Meskipun demikian, ubarampe yang diwujudkan dalam bentuk mentahan, orang Jawa tetap menyebutnya slametan. Dalam ikrarnya modin sering mengungkapkan bahwa ubarampe merupakan suatu sedekah (cara Islam), tetapi dalam undangan baik lisan maupun tertulis disebutnya sebagai undangan slametan. Dalam memenuhi undangan, untuk ukuran orang sekarang yang sehariharinya biasa makan dengan daging ayam potong dengan harga lumayan murah, belum tentu mau memakan ubarampe slametan, karena jenis menunya dianggap sama. Masyarakat mengatakan, jenis menu hidangan di rumah sering lebih bagus dibanding ubarampe slametan.

Oleh karena sifat kebudayaan itu dinamis, maka sinkretisme juga dinamis. Sebagai contoh sinkretisme yang diwujudkan dalam tradisi slametan, tahlilan, Yasinan, ziarah, metik, tedun, wayangan, 
golek dina, sesaji, ngalap berkah, cari dukun, dari dulu hingga sekarang tidak sama. Orang sekarang mengetahui tradisi slametan, tahlilan, Yasinan, dan ziarah adalah apa yang terlihat sekarang. Mereka tidak mengetahui bahwa tradisi tersebut sebenarnya telah turun-temurun serta mengalami berbagai tahap perubahan. Namun demikian, tradisi yang turun-temurun tetap memperlihatkan adanya benang merah, yaitu hadirnya doa-doa Islami sebagai roh serta perangkat-perangkat lokal sebagai wadah dalam budaya Islam sinkretis.

Baik doa-doa Islami maupun perangkat lokal tidak diikat oleh aturan tertentu. Seperti dalam slametan, doa-doa Islami misalnya alamin diucapkan ngalamin, alaikum diucapkan ngalaikum, bismillah diucapkan semilah, Muhammad diucapkan Mukamad, ini diperbolehkan atau sah. Pemimpin doa yang biasa disebut $\mathrm{kaum} / \mathrm{rois} /$ modin tidak harus lulusan pondok pesantren, tetapi boleh berasal dari latar belakang apa saja yang penting asal bisa berdoa. Demikian pula perangkat-perangkat lokal (ubarampe) misalnya nasi, lauk, gudangan, jajan pasar, dan buah-buahan tidak harus lengkap dan sesuai tradisi, tetapi boleh diganti dengan nasiayam goreng-sambal dan nasi-lele-sambal dengan tujuan lebih praktis. Bahkan akhir-akhir ini, perangkat lokalnya tidak menghadirkan makanan matang tetapi telah diganti dengan makanan mentah seperti beras, gula, supermie, telur mentah, dan teh. Meskipun demikian, perubahan-perubahan itu tidak menjadikan konflik di masyarakat, dan sebaliknya slametan itu mementingkan keharmonisan masyarakat.

Simuh menyebutkan bahwa sinkretisme dalam beragama (kepercayaan) adalah suatu sikap atau pandangan yang tidak mempersoalkan benar salahnya suatu agama. Bagi yang menganut paham ini semua agama dipandang baik dan benar. Oleh karena itu, para penganut sinkretisme berusaha memadukan unsur-unsur yang baik dari berbagai agama, yang tentu saja berbeda antara satu dengan lainnya, dan dijadikan suatu aliran, sekte, dan bahkan agama (Simuh, 1988: 12). Dari pernyataan Simuh mengandung 
muatan bahwa di dalam sinkretisme yang terpenting adalah keharmonisan.

Dalam mengikuti tradisi slametan, kadang-kadang orang sekedar melaksanakan untuk membuang fitnah. Tujuannya agar tidak menimbulkan friksi-friksi sosial, karena masyarakat sering menganggap sebagai ora umum, ora lumrahe wong Jawa (tidak umum atau orang Jawa yang tidak wajar) bagi orang yang tidak mau mengadakan slametan. Hal ini mengakibatkan kadang-kadang orang merasa terpaksa untuk mengadakan slametan. Jadi yang dilakukannya bukan atas kesadaran.

Dalam skala slametan yang lebih besar seperti di tempattempat keramat, berbagai kalangan termasuk orang Muhammadiyah di antaranya juga ikut mendukung dengan memberikan pasokan dana penyelenggaraan. Hal ini terjadi dalam tradisi slametan bersih desa di Wit Ketos dan sadranan di makam Ronggowarsito. Bahkan ada orang Muhammadiyah yang mau datang dalam ritual di sebuah pohon keramat. Memang perilaku keagamaan itu sering didasarkan pada dua aspek, yaitu kesadaran dan keterpaksaan. Bagi orang Jawa, dua aspek tersebut lebih banyak dihindarkan dengan tujuan agar harmonisasi sosial kehidupan kemasyarakatan bisa tercapai, sebagaimana diwujudkan dalam bentuk berkumpul bersama dalam suatu wadah ritual sinkretis yang disebut slametan. Hal inilah yang dibahas Geertz (1989) dan Beatty (2001) dalam wadah itu terdapat berbagai lapisan sosial dan kepercayaan berkumpul bersama (terintegrasi), duduk berjejer membentuk lingkaran, yang dipimpin oleh seorang modin. Sang modin memimpin upacara tersebut memakai bahasa Jawa dan Arab. Khususnya dalam melafalkan kata-kata Arab tidak terlalu fasih, tetapi ia tetap dipercaya masyarakat sebagai pemimpin slametan.

Dalam suatu mayarakat agraris-pedesaan (pedalaman) dengan ikatan tradisi sinkretis yang kuat, dipengaruhi oleh aspekaspek tradisi masyarakat lokal yang amat kental, akan membentuk ikatan kultural kuat dan terbentuknya integrasi sosio-budaya yang 
kuat. Kuatnya 'tembok' tradisi masyarakat sering menyulitkan gerakan pemurnian Islam untuk menembus wilayah tradisi masyarakat yang sinkretis. Oleh karena itu dalam rangka menjebol tembok sinkretis, gerakan pemurnian Islam melakukan tindakan radikal, dan akibatnya terjadilah benturan budaya. Benturan budaya menjadikan masyarakat petani pendukung tradisi masyarakat menghadapi dua pilihan yang saling kontradiksi, yaitu: (1) memilih tetap menjadi pendukung tradisi masyarakat, dan (2) berganti atau menyeberang haluan menjadi penentang tradisi masyarakat atau ikut dalam gerakan pemurnian Islam.

Mereka benar-benar menyeberang menjadi penganut Islam murni. Penyeberangan ini mengindikasikan bahwa masyarakat petani yang biasa menjadi pendukung tradisi masyarakat mengalami transformasi budaya menjadi mayarakat berbudaya puritan (gerakan pemurnian Islam). Kemudian kelompok yang kedua adalah mereka yang masih setia telah menjadi penganut gerakan pemurnian Islam tetapi masih setia mendukung tradisi masyarakat. Dalam upacara slametan sering golongan puritan ikut dalam satu wadah masyarakat sinkretis, dan hal ini menunjukkan bahwa tesis Mulder (1988) yang menyebutkan bahwa sinkretisme merupakan usaha untuk menyatukan sekte-sekte yang berbeda adalah benar.

Dalam hal sinkretisme sebagai wahana integrasi dari berbagai sekte yang berbeda perlu mendapat sorotan kembali, mengingat Mulder (1988) melihat terintegrasinya sekte-sekte itu hanya pada tataran permukaan, sedangkan jika ditelusuri dari dalam (batin orang Jawa) kurang representatif, karena ia tidak menjelaskan aspek rasa (perasaan). Sebagai contoh sikap komunalisme orang puritan dalam menghadiri slametan atau memberikan pasokan uang untuk mendukung acara tradisi masyarakat bersih desa, dalam perspektif Franz Magnis Suseno (1988) merupakan wujud tepa selira, perkewuh (rasa tidak enak). Meskipun ia sebagai orang puritan merasa tidak enak dengan tetangga yang mengadakan kegiatan tradisi masyarakat dalam bentuk upacara slametan bersih desa itu. 
Selain itu, masyarakat Jawa juga merasa tertuduh seandainya mereka membangkang tidak ikut kegiatan tradisi masyarakat. Sebagai bentuk partisipasi meskipun dalam skala kecil dukungannya, masyarakat Jawa tetap memperlihatkan diri. Sebetulnya ia membangkang, tetapi meskipun sedikit tetap memberikan dukungan. Hal ini yang disebut ngono ya ngono ning aja ngono (membangkang tetapi tidak begitu menyolok), atau meskipun hatinya membangkang tetapi secara fisik masih terlihat mendukung tradisi masyarakat.

Demikian juga, masyarakat Jawa memiliki sikap njawani atau sikap orang Jawa dengan cara mendukung tradisi masyarakat Jawa. Dalam perspektif Hildred Geertz (1961), salah satu sikap njawani adalah rasa sungkan (tidak enak di mata orang lain). Dengan rasa sungkan, orang menghadiri upacara slametan, meskipun ia puritan. Padahal jika diteropong melalui medium rasa, orang puritan (baca: Muhammadiyah) yang menghadiri slametan dan pasok uang untuk tradisi bersih desa hanya sekadar partisipasi semu atau dalam perspektif Marx (Ritzer, 2000) disebut kesadaran palsu (false consciousness). Dilihat dari penampilannya (luarnya) orang Muhammadiyah itu mendukung sinkretisme, tetapi dari dalam hatinya mendongkol atau perasaannya menentang. Dengan demikian jika diselami berdasarkan aspek perasaan, sinkretisme yang berwujud dalam bentuk slametan (termasuk di dalamnya yasinan, tahlilan) juga merupakan arena pertentangan atau wahana konflik antara orang orang sinkretis dan puritan. Penjelasan ini membuktikan bahwa tesis Mulder masih terdapat celah kelemahan, karena konsepnya tidak melibatkan aspek rasa.

Aspek perasaan bagi masyarakat Jawa dapat membuat persatuan, berkumpul bersama, dan berbaur dalam wadah tradisi masyarakat yaitu upacara. Bukan karena menu makanan yang lezat dan mewah. Bukan karena fasihnya sang modin membacakan doa dan pujian Islami. Bukan karena kedudukan sosial dalam masyarakat sebagai kelas bangsawan dan priyayi. Bukan karena penganut Muhammadiyah atau NU, dan akhirnya bukan karena sebagai 
santri ataupun abangan. Tetapi mereka berkumpul bersama untuk mendoakan kerabat yang sedang terkena musibah atau punya kerja. Dalam berkumpul bersama, semuanya saling mengerti satu sama lain. Jika terdapat kekuarangan, semua yang hadir bisa memaklumi. Akibatnya perbedaan-perbedaan dalam segala hal tidak pernah dibahas. Bahkan kekuatan sinkretisme inilah mampu mengikis habis segala perbedaan. Di sinilah kekuatan sinkretisme dalam tradisi masyarakat dapat terbangun rapi, meskipun sekarang ini sedang mendapat tekanan dari kelompok sosial gerakan pemurnian Islam.

\section{SIMPULAN}

Sinkretisme merupakan percampuran antara dua tradisi atau lebih, dan terjadi lantaran masyarakat mengadopsi suatu kepercayaan baru dan berusaha untuk tidak terjadi benturan dengan gagasan dan praktek budaya lama. Terjadinya percampuran tersebut biasanya melibatkan sejumlah perubahan pada unsur-unsur budaya atau tradisi yang diikutsertakan. Dalam hal ini, sinkretisme dipahami sebagai percampuran antara unsur-unsur budaya yang menyatu yaitu animisme, Hindu, dan Islam. .

Seperti tradisi masyarakat di Trucuk bercorak sinkretis, dalam arti terdapat perpaduan di antara dua atau lebih unsur tradisi atau budaya, misalnya animisme, Hindu, dan Islam. Hal tersebut seperti dinyatakan Geertz sebagai agama Jawa. Agama Jawa ini tampak dari luar adalah Islam, tetapi setelah dilihat secara mendalam kenyataannya adalah tradisi masyarakat yang bercorak sinkretis. Sepertinya tidak terjadi apa-apa bahwa sinkretisme itu menciptakan persatuan sebagai tujuan utama, akibatnya dogmadogma dan ajaran-ajaran harus dikurbankan secara lahiriyah, tetapi di dalamnya dogma-dogma dan ajaran-ajaran masih dipergunakan. Hal ini pula yang diklaim Mulder, tradisi masyarakat dalam bentuk upacara slametan itu terlihat dari doa-doanya, yang sepintas tampak Islami tetapi di dalamnya terkandung ajaran Hindu, Budha, dan animisme. Artinya, bahwa ajaran yang bercampur itu dapat 
disatukan. Dengan demikian apa yang diungkapkan Mulder (1992) adalah benar, bahwa sinkretisme merupakan usaha untuk menghilangkan perbedaan-perbedaan dan menciptakan persatuan (integrasi masyarakat) dari sekte-sekte yang berbeda. Kekuatan sikretisme inilah yang menjadikan tradisi masyarakat tetap hidup dan berkembang secara dinamis.

\section{DAFTAR PUSTAKA}

Abdurrahman, Moeslim. 2003. Muhammadiyah Sebagai Tenda Kultural. Jakarta: Ideo Press.

Beatty, Andrew. 2001. Variasi Agama di Jawa: Suatu Pendekatan Antropologi. Jakarta: PT Rajagrafindo Persada.

Geertz, Hildred. 1961. The Javese Family: A Study of Kinship and Sosialization. New York: The Free Press of Glencoe.

Geertz, Clifford. 1982. Islam Yang Penulis Amati: Perkembangan di Maroko dan Indonesia. Jakarta: Yayasan Ilmu-ilmu Sosial.

Koentjaraningrat. 1980. Pengantar Ilmu Antropologi. Jakarta: Aksara Baru.

1984. Kebudayaan Jawa. Jakarta: Balai Pustaka.

Mulder, Niels. 1992. "Sinkretisme Agama atau Agama Asia Tenggara?" Basis, Agustus, p. 285.

Ritzer, George. 2000. Sociological Theory. Singapore: McGrawHill Book Co.

Suseno, Frank Magnis. 1988. Etika Jawa: Sebuah Analisa tentang Falsafi Kebijaksanaan Hidup Jawa. Jakarta: PT Gramedia Pustaka Utama. 